\title{
ON DESIGN FEATURES OF PROPPED AND UNPROPPED HYPERSTATIC STRUCTURES
}

\author{
Algirdas Kudzys ${ }^{1}$, Romualdas Kliukas ${ }^{1}$, Antanas Kudzys ${ }^{2}$ \\ ${ }^{1}$ Vilnius Gediminas Technical University, Saulètekio al. 11, LT-10223 Vilnius, Lithuania \\ E-mail:pirmininkas@adm.vgtu.lt \\ ${ }^{2}$ Institute of Architecture and Construction of Kaunas University of Technology, Tunelio g. 60, \\ LT-44405 Kaunas, Lithuania.E-mail: asi@asi.lt \\ Received 10 July 2006; accepted 27 Nov 2006
}

\begin{abstract}
An effect of structural and technological features on the design methodology of hyperstatic precast reinforced concrete and composite steel-concrete structures is discussed. Permanent and variable service, snow and wind loads of buildings and their extreme values are analysed. Two loading cases of precast reinforced concrete and composite steelconcrete continuous and sway frame beams as propped and unpropped members are considered. A redistribution of bending moments for the ultimate limit state of beams is investigated. A limit state verification of hyperstatic beams by the partial factor and probability-based methods is presented. It is recommended to calculate a long-term survival probability of beams by the analytical method of transformed conditional probabilities.
\end{abstract}

Keywords: continuous beams, frame beams, propped structures, actions, partial factor method, probabilistic reliability.

\section{Introduction}

Composite steel-concrete structures and their construction technique utilise distinct advantages of steel and concrete components using the properties of materials as defined in Eurocode 2 [1] and Eurocode 3 [2]. A propping of horizontal members during their construction period is characteristic not only of composite structures but also of precast reinforced concrete continuous and frame beams. Hyperstatic composite and concrete systems of buildings and similar construction works exposed to extreme gravity and lateral actions belong to highreliable structures. Usually, a failure probability of these systems may be assessed as subjective predicted degree of dangerous event occurrence which cannot be observed frequently.

Composite steel-concrete and cracking reinforced concrete hyperstatic structures, usually, cannot collapse without warning. The potential damage of propped and unpropped structures should be limited reducing the hazards which their members are to sustain during construction and service periods. The hazards and structural failures can be caused not only by irresponsibility and gross human errors of designers and buildings engineers but also by some imperfect recommendations and directions presented in design codes and standards.

According to Eurocodes [1-3], the reliability required for load-carrying structures can be achieved by an appropriate execution (construction-erection) and quality management measures. Unfortunately, real proposals, recommendations and specific features considering the effect of construction technology on structural safety of buildings are passed over in silence. This shortage is visually revealed in the analysis of the load-carrying capacity and safety of continuous beams and frames with propped and unpropped members.

It is difficult to assess quantitatively the reliability of hyperstatic systems and their members by deterministic design code recommendations. Therefore in some cases it can lead to groundless overestimation or underestimation of the reliability of designed and existing structures. The probability-based concepts and approaches allow us to calculate quantitative reliability indices. However, it is difficult to implant the probabilistic methods in design practice due to some methodological and mathematical troubles.

The purpose of this paper is to turn an attention of structural engineers to design features of hyperstatic structures consisting of propped and unpropped members and to encourage designers having a minimum appropriate skill and experience to use the probability-based methods in their design practice.

\section{Hyperstatic structures and their actions}

Travelling crane girders, continuous beams of cargo piers, non-sway multi-storey buildings or construction works with three or more supports and continuous slabs belong to the simplest hyperstatic concrete structures. Continuous beams, usually, are constant in cross-section, have effective reinforcement at internal supports and may generally be analysed on the assumption that the supports provide no rotational restraints and do not transfer bending moments to the beams. In an elastic analysis, their action effects may be calculated using tabulated ratios of negative and positive bending moments. 
Single-storey and multi-storey sway frames as the complex hyperstatic systems are capable to response to bending and torsion moments, axial and shear forces caused not only by gravity but also by lateral variable actions. Multi-storey moment-resisting sway systems are used as load-carrying frameworks of offices, residential and industrial buildings. To these systems also belongs a combination of reinforced concrete floor slabs and walls with rigid floor-wall joints. Beam-column and floor-wall joints may be treated as rigid because their deformations have no significant influence on the distribution of internal moments and forces.

Composite steel-concrete columns, beams and slabs of hyperstatic systems consist of concrete and structural or cold-formed steel sections. The steel sections of composite beams are either continuous over internal supports or are joined by full-strength and rigid connections. The steel sections of composite beams may be propped until the concrete components are able to resist action effects (loading case $A$ ). The weight of concrete components may also be applied to steel beams (loading case $B$ ). Analogically, the precast reinforced concrete beams may be presented as propped or unpropped members. Beams of precast concrete frames may be treated as unpropped members in which the weight of floor structures is applied before beam and frame joints are able to resist action effects.

Usually, action effects of load-carrying structures of buildings are caused by the mass of erected members $g_{1}$, additional permanent mass of superstructures $g_{2}=g-g_{1}$, time-dependent sustained $q_{1}(t)$ and extraordinary $q_{2}(t)$ or snow $s(t)$ variable loads and wind actions $w(t)$. All service loads which do not belong to sustained actions may be treated as extraordinary live load components. According to Rosowsky and Ellingwood [4], the annual extreme sum of sustained and extraordinary loads $q(t)=q_{1}(t)+q_{2}(t)$ can be modelled as an intermittent rectangular pulse process and described by a Type 1 (Gumbel) distribution with the mean $q_{m}=0,47 q_{k}$ and coefficient of variation $\boldsymbol{\delta} q=0,58$, where $q_{k}$ is the characteristic extreme load.

The probability distribution of permanent loads $g$ is close to a Gaussian distribution with the coefficient of variation $\delta g=0,05-0,15$. It is proposed to model the annual extreme snow and wind loads by Gumbel distribution with the coefficients of variation, respectively, $\boldsymbol{\delta} s=0,30-0,70$ and $\boldsymbol{\delta} w=0,30-0,50[3,5-13]$.

The joints of propped continuous or braced frame beams are able to resist all action effects caused by permanent and variable actions (Fig 1a). Quite the reverse, the action effects at joints of redundant systems erected with unpropped precast beams are caused only by additional permanent and all variable gravity and wind actions (Fig 2b). The mentioned features of construction technology of hyperstatic systems have some influence on the structural behaviour of continuous and frame beams and must be assessed in their bearing capacity and structural safety analysis. Moreover, total structural safety of hyperstatic structures depends on the integrity of steel and concrete components and on the ductility performance of members and their joints.

\section{Action effects and their redistribution}

The complete assemblages of horizontal and vertical members of hyperstatic structures may be idealised as a non-linear frame system of their nodal points connected by linear members. In general, the analysis of hyperstatic systems should be based on the dynamic model characterising their inertia, damping and stiffness properties. The non-linear equilibrium equation or, the so-called, tangential equation in motion of systems may be written as follows:

$$
\boldsymbol{M} \ddot{\boldsymbol{U}}+\boldsymbol{C} \dot{\boldsymbol{U}}+\boldsymbol{K} \boldsymbol{U}=\boldsymbol{L},
$$

where $\boldsymbol{M}, \boldsymbol{C}$ and $\boldsymbol{K}$ are the mass, damping and stiffness matrixes; $\ddot{\boldsymbol{U}}, \dot{\boldsymbol{U}}$ and $\boldsymbol{U}$ are the nodal accelerations, velocities and displacements vectors; $\boldsymbol{L}$ is the united vector of stochastically independent gravity and lateral actions [13]. If inertia forces do not need to be introduced, the equilibrium Eq 1 may be expressed as follows:

$$
\boldsymbol{K} \boldsymbol{U}=\boldsymbol{L} .
$$

Practically, the non-linear response analysis of hyperstatic systems of buildings is generally carried out using incremental loading procedures with equilibrium iterations. The tangent stiffness matrix $\boldsymbol{K}$ can be accepted constant between two successive states of deteriorated systems with cracking members.

The time-dependent united vector of stochastically independent gravity and lateral actions represents the random process as follows:

$$
\boldsymbol{L}(t)=\boldsymbol{G}_{1}+\boldsymbol{G}_{2}+\boldsymbol{Q}_{1}(t)+\boldsymbol{Q}_{2}(t)+\boldsymbol{W}(t) .
$$

The mean and variance of the probability distribution of united action effects can be calculated by the formulae;

$$
\begin{gathered}
S_{m} \equiv\left(M_{m} ; N_{m} ; V_{m}\right)=\boldsymbol{\alpha}^{\mathrm{T}} \boldsymbol{L}_{m}(t) \\
\boldsymbol{\sigma}^{2} S=\boldsymbol{\sigma}^{2} S_{g_{1}}+\boldsymbol{\sigma}^{2} S_{g_{2}}+\boldsymbol{\sigma}^{2} S_{q_{1}}(t)+\boldsymbol{\sigma}^{2} S_{q_{2}}(t)+\boldsymbol{\sigma}^{2} S_{w}(t)
\end{gathered}
$$

Here $\alpha^{\mathrm{T}}$ is the row vector of an effect influence matrix.

When the determination of the action effects of hyperstatic systems is based on the theory of elasticity, the possible redistribution of these effects for the ultimate limit state may be used. The bending moments (and shear forces) may be redistributed provided that the resulting their distributions remains in equilibrium with the applied actions. The moment reduction (specification) factor $\delta=M_{u} / M_{e l}$ is the ratio of the redistributed support moment on the joint face to the elastic bending moment. According to Eurocode $2[1,14]$, a redistribution of bending moments of concrete hyperstatic systems may be carried out without explicit check on the rotation capacity provided that:

$$
\delta \geq 0,4+\left[0,6+\left(0,0014 / \varepsilon_{c u}\right)\right] x_{u} / d,
$$

where $x_{u}$ and $d$ are the depths of a neutral axis and a cross-section; $\varepsilon_{c u}$ is the ultimate concrete strain in compression. 
a) Loading case $A$

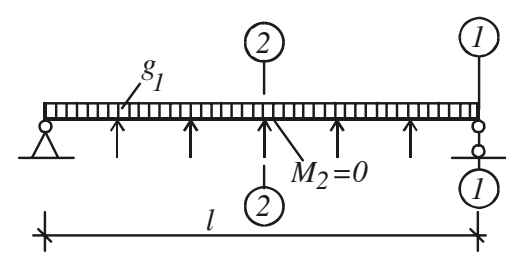

b) Loading case $B$

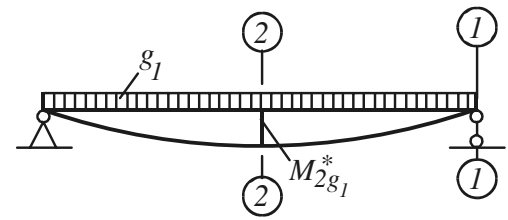

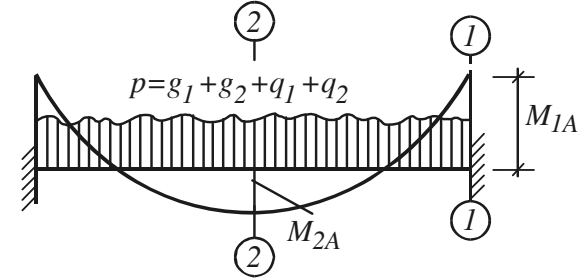

(2)

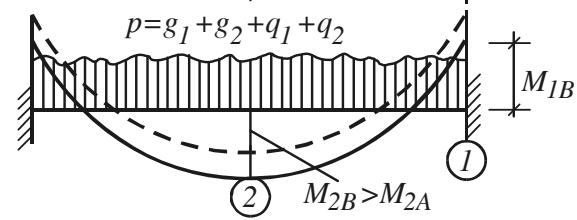

Fig 1. Gravity loads and bending moments of middle propped (a) and unpropped (b) continuous or braced frame beams

a) Loading case $A$

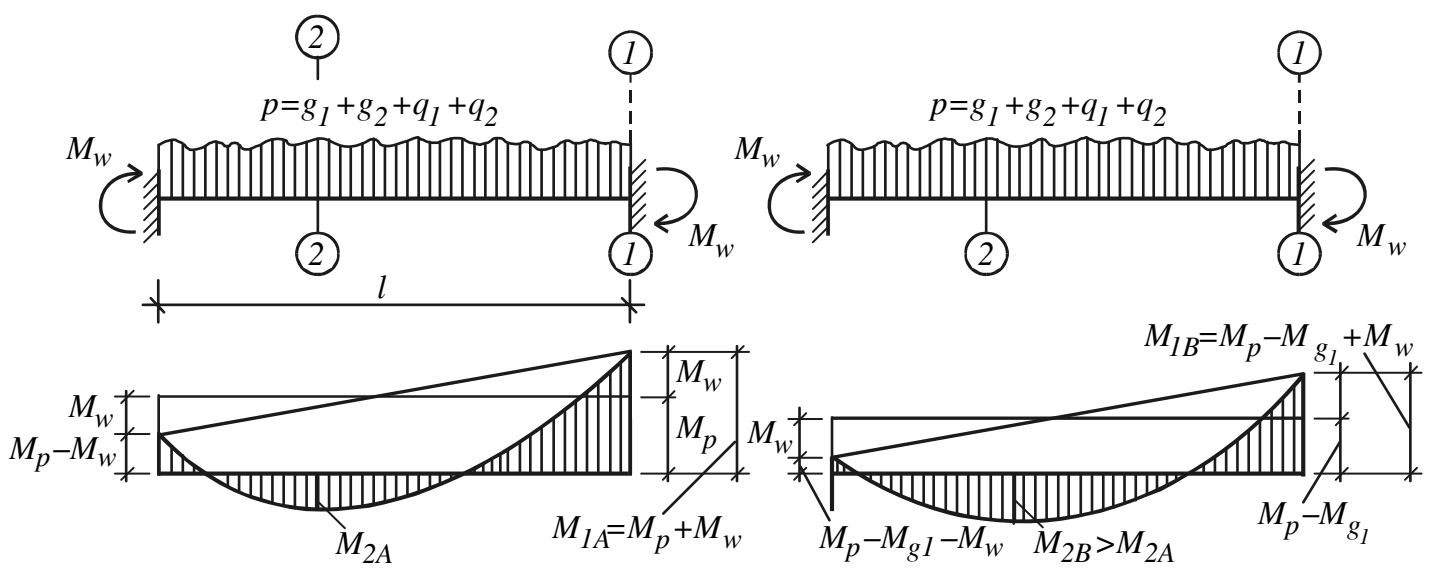

Fig 2. Loads and bending moments of in-situ or propped (a) und unpropped (b) precast and composite middle beams of sway frames

The moment reduction factor, $\delta$, for composite beams depends on the class of reinforcement and cracking of their cross-sections and is equal to $\delta=0,60-0,90$ [15]. However, elastic moments may not be reduced in concrete and composite columns.

In structural safety analysis, it is expedient to acknowledge a quantitative redistribution of action effects of cracking hyperstatic systems not in their motion stage, but before steel yielding process. When the continuous and frame beams are cracked in adjacent two column sections, the redistribution factor $\delta_{A} \approx 0,8$ and $\delta_{B}=0,9-1,0$ for in-situ or propped and unpropped precast concrete and composite steel-concrete beams, respectively.

\section{Bending moments of continuous beams}

The bending moments at support (1-1) and span (2-2) sections of propped and unpropped continuous or non-sway frame beams are presented in Fig 1. It is not difficult to satisfy oneself that the span moment of unpropped beams in construction stage may be much greater than that predicted using classical structural mechanics methods and ignoring the role of permanent load features.

The bending moment distribution given by an elastic analysis of continuous concrete and composite beams may be redistributed. The total modified bending moments of propped (loading case $A$ ) and unpropped (loading case $B$ ) middle beams are:

$$
\begin{gathered}
M_{1 A}=M_{1 g_{1}}+M_{1 g_{2}}+M_{1 q_{1}}+M_{1 q_{2}}=\delta_{A} p_{A} l^{2} / 12, \\
M_{2 A}=M_{2 g_{1}}+M_{2 g_{2}}+M_{2 q_{1}}+M_{2 q_{2}}= \\
p_{A} l^{2}\left(1 / 8-\delta_{A} / 12\right) \\
M_{1 B}=M_{1 g_{2}}+M_{1 q_{1}}+M_{1 q_{2}}=\delta_{B} p_{B} l^{2} / 12 \\
M_{2 B}=M_{2 g_{1}}^{*}+M_{2 g_{2}}+M_{2 q_{1}}+M_{2 q_{2}}= \\
\left(p_{A} / 8-\delta_{B} p_{B} / 12\right) l^{2} .
\end{gathered}
$$

Here $M_{2 g_{1}}^{*}$ is the bending moment of a single beam caused by permanent load $g_{1} ; \delta_{A}$ and $\delta_{B}$ are the moment reduction factors for propped and unpropped beams, respectively: 


$$
\begin{gathered}
p_{A}=g_{1}+g_{2}+q, \\
p_{B}=g_{2}+q,
\end{gathered}
$$

where $q=q_{1}+q_{2}$ and $q=s$ are the variable loads when floor and roof beams of buildings are under consideration.

\section{Bending moments of sway frame beams}

The bending moments of sway frame beams (Fig 2) and their redistributions are closely related to lateral wind loads. The total modified bending moments of propped (loading case A) and unpropped (loading case B) middle frame beams are:

$$
\begin{gathered}
M_{1 A}=\delta_{A}\left(p_{A} l^{2} / 12+M_{w}\right), \\
M_{2 A}=p_{A} l^{2}\left(1 / 8-\delta_{A} / 12\right)+\left[2 \delta_{A}^{2} M_{w}^{2} /\left(p_{A} l^{2}\right)\right], \\
M_{1 B}=\delta_{B}\left(p_{B} l^{2} / 12+M_{w}\right), \\
M_{2 B}=\left(p_{A} / 8-\delta_{B} p_{B} / 12\right) l^{2}+\left[2 \delta_{B}^{2} M_{w}^{2} /\left(p_{A} l^{2}\right)\right],
\end{gathered}
$$

where $p_{A}$ and $p_{B}$ are distributed gravity loads by (11) and (12). The quantities in square brackets may be ignored when the wind moment $M_{w} \leq 0,02 p l^{2}$.

\section{Safety margins of continuous and frame beams}

Structural reinforced concrete, steel and composite steel-concrete members (beams and columns) must be analysed at a sufficient number of cross and oblique sections to ensure that the requirements of design codes are satisfied at all sections along the beams and columns. The critical support and span sections may be treated as the particular members of load-carrying structures.

The performance as the safety margin process of the particular member may be written in the form:

$$
Z(t)=\theta_{R} R-\theta_{g}\left(S_{g_{1}}+S_{g_{2}}\right)-\theta_{q} S_{q}(t)-\theta_{w} S_{w}(t) .
$$

Here $R$ is the member resistance; $S_{g_{1}}$ and $S_{g_{2}}$ are the action effects caused by the mass of the load-carrying structures and additional permanent loads, respectively; $S_{q}(t)$ and $S_{w}(t)$ are the action effects caused by the gravity and lateral extreme variable actions; $\theta_{R}, \theta_{g}, \theta_{q}$ and $\theta_{w}$ are the additional variables representing the uncertainties of analysis models which give the values of resistance and action effects.

The time-dependent performance of particular members should be assessed taking into account all construction features of precast concrete and composite hyperstatic systems. When longitudinal forces may be ignored and the loading case A is considered (Fig 2a), the time-dependent safety margin of the normal section 1-1 of beams can be expressed as:

$$
Z_{1 A}(t)=R_{1 C A}-M_{1}(t) .
$$

Here the conventional resistance $R_{1 C A}$ and the bending moment $M_{1}(t)$ are:

$$
R_{1 C A}=\theta_{R} R_{1 A}-\theta_{g}\left(M_{g_{1}}+M_{g_{2}}\right),
$$

$$
M_{1}(t)=\theta_{q} M_{q}(t)+\theta_{w} M_{w}(t) .
$$

The probability distribution law of the conventional resistance $R_{1 C A}$ is close to the normal one.

When the loading case B exists (Fig 2b), the equations (18) and (19) can be re-expressed as:

$$
\begin{aligned}
& Z_{1 B}(t)=R_{1 C B}-M_{1}(t), \\
& R_{1 C B}=\theta_{R} R_{1 B}-\theta_{\mathrm{g}} M_{g_{2}},
\end{aligned}
$$

where the moment $M_{1}(t)$ by (20). For non-sway frames and continuous beams the extreme bending moment is:

$$
M_{1}(t)=\theta_{q} M_{q}(t)
$$

or

$$
M_{1}(t)=\theta_{s} M_{s}(t)
$$

when extreme action effects are caused by live service or snow loads.

\section{Safety of particular and structural members}

The recurrent rates of the extreme values of live service, snow and wind loads are $\lambda_{q}=\lambda_{s}=\lambda_{w}=1 /$ year [6, 16]. Therefore, it is expedient to consider the random safety margin process of particular members as the random sequence written in the form:

$$
Z_{k}=R_{C}-S_{k}, \quad k=1,2, \ldots, r,
$$

where $R_{C}$ is the conventional resistance of normal or oblique sections, $S_{k}$ - their bending moment or shear force and $r$ - the design working life of structures in years. A stochastical dependency of the sequence cuts is represented by the rank coefficient of correlation as:

$$
\rho_{\mathrm{kl}}=\operatorname{Cov}\left(Z_{k}, Z_{l}\right) /\left(\sigma Z_{k} \times \sigma Z_{l}\right)=1 /\left(1+\sigma^{2} S_{k} / \boldsymbol{\sigma}^{2} R_{C}\right),
$$

where $\operatorname{Cov}\left(Z_{k}, Z_{l}\right)$ and $\sigma Z_{k}, \sigma Z_{l}$ are the covariance and standard deviations of the random sequence cuts.

Resistances and action effects of beam sections may be treated as statistically independent. Therefore their instantaneous survival probability is:

$$
P_{k}=P\left\{Z_{k}>0\right\}=\int_{0}^{\infty} f_{R_{c}}(x) F_{S_{k}}(x) d x,
$$

where $f_{R_{c}}(x)$ and $F_{S_{k}}(x)$ are the density and distribution functions of conventional resistances and action effects, respectively. Its value may be calculated by Monte Carlo simulation, the numerical integration and limit transient action effect [17] methods.

According to the method of transformed conditional probabilities (TCPM) [18, 19], the long-term survival probability of particular members may be calculated by the formula:

$$
\begin{gathered}
\boldsymbol{P}_{i}=\boldsymbol{P}_{\boldsymbol{i}}\{Z(t)>0\}=\left\{\bigcap_{k=1}^{r}\left(R_{C}-S_{k}>0\right)\right\}= \\
\boldsymbol{P}_{k}^{r}\left[1+\rho_{k l}^{a}\left(\frac{1}{\boldsymbol{P}_{k}}-1\right)\right]^{r-1},
\end{gathered}
$$


where $\boldsymbol{P}_{k}$ is the probability by Eq $27 ; r$ - the number of annual extreme events; $\rho_{k l}-$ the coefficient by (26) and $a=\left[4,5 /\left(1-0,98 \rho_{k l}\right)\right]^{1 / 2}-$ its bond index.

The continuous and frame beams should be idealized as the auto-systems representing multicriteria failure mode due to various responses of particular members. The auto-systems of beams are characterised by stochastically dependent conventional elements in mixed connections (Fig 3). The survival probabilities of their elements as particular members of beams may be expressed as:

$\boldsymbol{P}_{1}=\boldsymbol{P}\left\{Z_{1}(t)>0\right\}, \quad \boldsymbol{P}_{2}=\boldsymbol{P}\left\{Z_{2}(t)>0\right\}, \boldsymbol{P}_{3}=\boldsymbol{P}\left\{Z_{3}(t)>0\right\}$.

Due to system redundancy, the reaching of the limit state in any one normal section 1 or 2 of beams does not mean their failure. But the failure of beams in any oblique section 3 implies the failure of the auto-system.

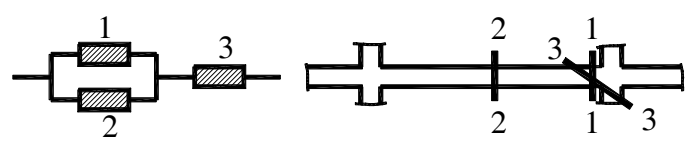

Fig 3. Mixed auto-system representation

The stochastical dependency of auto-system elements depend on the structural concept and construction technology features of hyperstatic structures and an intensity of extreme actions. For in-situ reinforced concrete and precast or composite beams, the coefficient of correlation of safety margins of particular members, usually, is equal to $0,6-1$ and $0,3-0,8$, respectively. The coefficients of correlation $\rho_{13}$ and $\rho_{23}$ are equal from 0,3 to 0,8 .

According to the TCPM, the survival probability of beam normal sections 1-1 and 2-2 as the parallel auto systems is:

$\boldsymbol{P}_{12}=\boldsymbol{P}_{12}\left\{T \geq t_{r}\right\}=\boldsymbol{P}_{1}+\boldsymbol{P}_{2}-\boldsymbol{P}_{1} \boldsymbol{P}_{2}\left[1+\rho_{12}^{a}\left(1 / \boldsymbol{P}_{1 / 2}-1\right)\right]$,

where $\boldsymbol{P}_{1 / 2}$ is the greater value than the probabilities $\boldsymbol{P}_{1}$ and $\boldsymbol{P}_{2}$,

$$
\rho_{12}=\operatorname{Cov}\left(Z_{1}, Z_{2}\right) /\left(\boldsymbol{\sigma} Z_{1} \times \boldsymbol{\sigma} Z_{2}\right),
$$

is the coefficient of cross-correlation of beam safety margins $Z_{1}$ and $Z_{2}$.

The total survival probability of continuous or frame beams as the mixed auto systems may be calculated by the formula:

$$
\begin{gathered}
\boldsymbol{P}_{123}=\boldsymbol{P}_{123}\left\{T \geq t_{r}\right\}=\boldsymbol{P}\left[\left(Z_{1}(t)>0 \bigcup Z_{2}(t)>0\right) \bigcap Z_{3}(t)>0\right]= \\
\boldsymbol{P}_{12} \boldsymbol{P}_{3}\left[1+\rho_{3 \mid 12}^{a}\left(1 / P_{3 / 12}-1\right)\right],
\end{gathered}
$$

where $\boldsymbol{P}_{12}$ by $(29), \rho_{3 \mid 12}=\left(\rho_{31}+\rho_{32}\right) / 2$.

The generalised reliability index is

$$
\beta=\Phi^{-1}(\boldsymbol{P}),
$$

where $\Phi^{-1}$ is the inverse standardised normal distribution. For beams of hyperstatic systems of reliability class $\mathrm{RC} 2$, the index $\beta$ must be not less as 3,8. For their normal sections as particular members, this index may be decreased to 3,5 .

\section{Numerical illustration}

\subsection{Resistance and load parameters}

Consider as an example the verification of availability of normal sections of precast members as frame middle beams of reliability class RC2 (Fig 4) the span of which is $l=5,7 \mathrm{~m}$. The cross-sectional area of reinforcing bars (3 $\varnothing 25$ ), the coefficient of variation, mean and variance of yield strength and its characteristic value are:

$A_{s 1}=A_{s 2}=A_{s}=14,72 \mathrm{~cm}^{2}, \boldsymbol{\delta} f_{y}=8 \%, f_{y m}=460 \mathrm{MPa}$, $\boldsymbol{\sigma}^{2} f_{y}=1354(\mathrm{MPa})^{2}, f_{y k}=400 \mathrm{MPa}$. The design yield strength is: $f_{y d}=f_{y k} / \gamma_{M}=400 / 1,15=347,8 \mathrm{MPa}$.

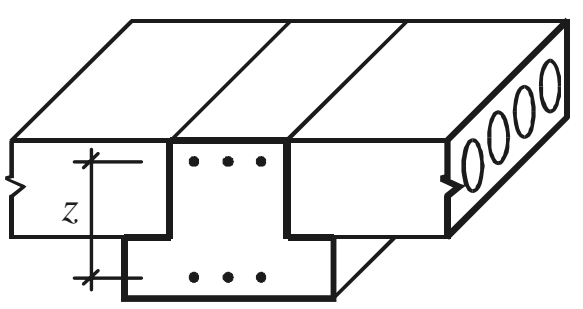

Fig 4. Precast floor beam and slabs

The mean and variance of couple arms of bending moments are: $z_{m}=32 \mathrm{~cm}^{2}, \boldsymbol{\sigma}^{2} z=2,56 \mathrm{~cm}^{2}$. Thus the design resistance of bending sections $1-1$ and 2-2 is:

$$
M_{R d}=f_{y d} A_{s} z=163,83 \mathrm{kNm} .
$$

When the parameters of the additional variable $\theta_{R}$ are equal to $\theta_{R m}=1,0$ and $\boldsymbol{\sigma}^{2} \theta_{R}=0,01$, the mean and variances of normal section resistances are:

$$
\left(\theta_{R} R\right)_{m}=R_{m}=f_{y m} A_{s} z_{m}=216,68 \mathrm{kNm}
$$

$\boldsymbol{\sigma}^{2} R=\left(A_{s} z_{m}\right)^{2} \boldsymbol{\sigma}^{2} f_{y}+\left(f_{y m} A_{s}\right)^{2} \boldsymbol{\sigma}^{2} z=417,84(\mathrm{kNm})^{2}$,

$\boldsymbol{\sigma}^{2}\left(\theta_{R} R\right)=\boldsymbol{\sigma}^{2} R+R_{m}^{2} \boldsymbol{\sigma}^{2} \theta_{R}=887,34(\mathrm{kNm})^{2}$.

The parameters of permanent and variable loads are: $g_{1 k}=g_{1 m}=23,2 \mathrm{kN} / \mathrm{m}, g_{2 k}=g_{2 m}=8,0 \mathrm{kN} / \mathrm{m}$, $\boldsymbol{\delta} g_{1}=\boldsymbol{\delta} g_{2}=10 \% ; \quad q_{k}=18,0 \mathrm{kN} / \mathrm{m}, \quad q_{m}=0,47 q_{k}=$ $8,46 \mathrm{kN} / \mathrm{m}, \boldsymbol{\delta} q=58 \%$. The parameters of wind moments are: $\quad M_{W k}=16,8 \mathrm{kNm}, \quad M_{W m}=M_{W k} /\left(1+k_{0.98} \delta W\right)=$ $9,45 \mathrm{kNm} . \boldsymbol{\delta} W=30 \%$. The parameters of the additional variable $\theta_{M}$ are: $\theta_{M m}=1,0$ and $\boldsymbol{\sigma}^{2} \theta_{M}=0,01$.

\subsection{Verification by the partial factor method}

Using the partial factor method, no ultimate limit state may be exceeded when design values for beam resistances $M_{R_{d}}$ and bending moments $M_{E_{d}}$ are considered. Design bending moments of beam normal sections 1-1 and 2-2 are calculated by Eq (7)-(10) and (13)-(16) using the design values of gravity loads $p_{A d}$ by (11), $p_{B d}$ by (12) and wind moments $M_{w d}$. 
Table 1. The parameters of bending moments and resistances of normal sections

\begin{tabular}{|c|c|c|c|c|c|c|c|c|c|c|c|}
\hline \multirow[b]{2}{*}{ ڤ્ञ } & \multirow{2}{*}{ 节 } & \multicolumn{2}{|c|}{ Load $g$} & \multicolumn{2}{|c|}{ Load $q$} & \multicolumn{2}{|c|}{ Wind $w$} & \multicolumn{2}{|c|}{$q+w$} & \multicolumn{2}{|c|}{$R_{c}$} \\
\hline & & $\begin{array}{c}\left(\theta M_{g}\right)_{m} \\
\mathrm{kNm}\end{array}$ & $\begin{array}{c}\boldsymbol{\sigma}^{2}\left(\theta M_{g}\right) \\
(\mathrm{kNm})^{2}\end{array}$ & $\begin{array}{c}\left(\theta M_{q}\right)_{m} \\
\mathrm{kNm}\end{array}$ & $\begin{array}{c}\boldsymbol{\sigma}^{2}\left(\theta M_{q}\right) \\
(\mathrm{kNm})^{2}\end{array}$ & $\left(\begin{array}{c}\left(\theta M_{w}\right)_{m} \\
\mathrm{kNm}\end{array}\right.$ & $\begin{array}{c}\boldsymbol{\sigma}^{2}\left(\theta M_{w}\right) \\
(\mathrm{kNm})^{2}\end{array}$ & $\begin{array}{c}M_{m} \\
\mathrm{kNm}\end{array}$ & $\begin{array}{c}\boldsymbol{\sigma}^{2} M \\
(\mathrm{kNm})^{2}\end{array}$ & $\begin{array}{c}R_{c m} \\
\mathrm{kNm}\end{array}$ & $\begin{array}{c}\boldsymbol{\sigma}^{2} R_{c} \\
(\mathrm{kNm})^{2}\end{array}$ \\
\hline \multirow[b]{2}{*}{$\begin{array}{l}\text { Pro- } \\
\text { pped }\end{array}$} & $1-1$ & 67,58 & 91,34 & 18,32 & 116,32 & 7,56 & 5,72 & 25,88 & 122,04 & 149,1 & 978,68 \\
\hline & $2-2$ & 59,13 & 69,93 & 19,48 & 131,45 & - & - & 19,48 & 131,45 & 157,55 & 957,27 \\
\hline \multirow{2}{*}{$\begin{array}{l}\text { Unp- } \\
\text { ropped }\end{array}$} & $1-1$ & 21,66 & 9,38 & 22,91 & 181,81 & 9,45 & 8,93 & 32,36 & 190,74 & 195,02 & 896,78 \\
\hline & $2-2$ & 105,05 & 200,30 & 11,45 & 45,45 & - & - & 11,45 & 45,45 & 116,63 & 1087,64 \\
\hline
\end{tabular}

Table 2. The survival probabilities and reliability indices or normal sections

\begin{tabular}{|c|c|c|c|c|c|c|c|}
\hline \multirow{2}{*}{ Beams } & \multirow{2}{*}{ Sections } & \multirow{2}{*}{$\begin{array}{c}\rho_{k l} \\
\text { by }(26)\end{array}$} & \multirow{2}{*}{$\begin{array}{c}\boldsymbol{P}_{k} \\
\text { by }(27)\end{array}$} & \multirow{2}{*}{$\begin{array}{c}\boldsymbol{P}_{i} \\
\text { by }(28)\end{array}$} & \multicolumn{2}{|c|}{ Indices } & \multirow{2}{*}{ Reinforcing } \\
\hline & & & & & $\beta$ & $\beta_{\text {tar }}$ & \\
\hline \multirow{2}{*}{ Propped } & $1-1$ & 0,8891 & $0,9^{3} 823$ & $0,9^{2} 549$ & 2,61 & 3,5 & Irreliable \\
\hline & $2-2$ & 0,8792 & $0,9^{4} 614$ & $0,9^{2} 898$ & 3,09 & 3,5 & Irreliable \\
\hline \multirow{2}{*}{ Unpropped } & $1-1$ & 0,8246 & $0,9^{5} 266$ & $0,9^{3} 771$ & 3,51 & 3,5 & Reliable \\
\hline & $2-2$ & 0,9599 & $0,9^{2} 847$ & 0,9763 & 1,98 & 3,5 & Inadmissible \\
\hline
\end{tabular}

The live load $q$ is a leading variable action. According to (11) and (12), the design gravity loads are:

$$
\begin{gathered}
p_{A d}=g_{1 k} \gamma_{G}+g_{2 k} \gamma_{G}+q_{k} \gamma_{Q}=23,2 \times 1,35+8,0 \times \\
1,35+18,0 \times 1,5=69,12 \mathrm{kN} / \mathrm{m}, \\
p_{B d}=g_{2 k} \gamma_{G}+q_{k} \gamma_{Q}=8,0 \times 1,35+18,0 \times 1,5=37,8 \mathrm{kN} / \mathrm{m} .
\end{gathered}
$$

The design wind moment is:

$M_{w d}=M_{w k} \psi_{o} \gamma_{w}=16,8 \times 0,7 \times 1,5=17,64 \mathrm{kN} \cdot \mathrm{m}<$ $0,02 p l^{2}$.

According to (13)-(16), the design values of bending moments are:

$M_{1 A E_{d}}=0,8\left(69,12 \times 5,7^{2} / 12+17,64\right)=163,82 \mathrm{kN} \cdot \mathrm{m} \approx$

$M_{1 R_{d}}=163,83 \mathrm{kNm}$ (a rational solution),

$M_{2 A E_{d}}=69,12 \times 5,7^{2}(1 / 8-0,8 / 12)=131 \mathrm{kNm}<M_{2 R_{d}}=$ $163,83 \mathrm{kNm}$ (a logical solution),

$M_{1 B E_{d}}=1,0 \quad\left(37,8 \times 5,7^{2} / 12+17,64\right)=119,98 \mathrm{kNm}$

$<<M_{1 R_{d}}=163,83 \mathrm{kNm}$ (an irrational solution),

$M_{2 B E_{d}}=69,12 \times 5,7^{2} / 8-1,0 \times 37,8 \times 5,7^{2} / 12=$

$178,37 \mathrm{kN} \cdot \mathrm{m}>M_{2 R_{d}}=163,83 \mathrm{kNm}$ (an inadmissible solution).

According to the partial factor method, the unpropped precast members are irreliable for considered frame beams.

\subsection{Verification by the probability-based model}

The results on safety design of the normal sections of frame middle beams are presented in Tables 1 and 2.

Contrary to the results of the partial safety factor design (section 8.2), the reliability indices presented in Table 2 show that not only unpropped but also propped precast members must be treated as irrationally reinforced and irreliable beams of considered frames.

\section{Conclusions}

The analysis of hyperstatic reinforced concrete and composite steel-concrete structures subjected to action effects caused by service and climate actions depends on the features of structural concepts and construction technologies. Therefore, different design approaches and models must be used in load-carrying capacity and reliability predictions of hyperstatic systems consisting of propped and unpropped bending members.

The values of annual extreme service, snow and wind loads may be treated as basic action variables. In addition, they are closely related to characteristic values of actions used in the partial factor method. Therefore it is recommended to use extreme variable effects of actions when a limit state verification of hyperstatic structures is carried out by probability-based approaches.

For the sake of design simplifications, it is expedient to base the structural safety analysis of members on the concepts of conventional resistances and safety margin sequences. The long-term survival probabilities of normal or oblique sections as particular members having one single failure mode and beams as structural mixed auto systems representing multicriteria failure mode may be calculated by the method of unsophisticated transformed conditional probabilities.

In some cases, it may be expedient to design and fabricate precast concrete and composite steel-concrete beams as propped members of hyperstatic structures. These beams may be supported until their joints are able to resist stresses.

\section{References}

1. EN 1992-1-1: 2002E. Eurocode 2: Design of concrete structures - Part 1: General rules and rules for buildings. European Committee for Standardization, Brussels, Belgium, 2002. $230 \mathrm{p}$.

2. EN 1993-1-1: 2002E. Eurocode 3: Design of steel structures - Part 1-1: General rules and rules for buildings. European Committee for Standardization, Brussels, Belgium, 2002. $344 \mathrm{p}$. 
3. EN 1990: 2002E. Eurocode 1: Basis of structural design. European Committee for Standardization, Brussels, Belgium, 2002. $87 \mathrm{p}$.

4. ROSOWSKY, D.; ELLINGWOOD, B. Reliability of wood systems subjected to stochastic live loads. Wood and Fiber Science, 1992, 24(1), p. 47-49.

5. ISO 2394. General principles of reliability of structures. Switzerland, 1998. $73 \mathrm{p}$.

6. ELLINGWOOD, B. R.; TEKIE, P. B. Wind load statistics for probability-based structural design. Journal of Structural Engineering, ASCE, 1999, 125(4), p. 453-463.

7. RAIZER, V. P. Theory of reliability in structural design. Moscow: ACB Publishing House, 1999. 302 p. (in Russian).

8. MELCHERS, R. E. Structural reliability analysis and prediction. Chichester: John Wiley, 1999. 437 p.

9. JCSS. Probabilistic Model Code: Part 1-Basis on design. Joint Committee on Structural Safety, 2000. 62 p.

10. ASCE Standard No 7-05. Minimum design loads for buildings and other structures. American Society of Civil Engineers, 2006. 424 p.

11. SÝKORA, M. Load combination model based on intermittent rectangular wave renewal processes. In Proc of $9^{\text {th }}$ International Conference on Structural Safety and Reliability ICOSSAR'05, Rome, Italy, June 19-23, 2005. Ed G. Augusti, G. I. Schueller and M. Ciampoli. Rotterdam: Millpress, 2005, p. 2517-2524.
12. MORI, V.; KATO, R.; MURAI, K. Probabilistic models of combinations of stochastic loads for limit state design. Structural Safety, 2003, 25(1), p. 69-97.

13. SCHUEREMANS, L.; VAN GEMERT, D. Assessing the safety of existing structures: reliability based assessment framework, examples and application. Journal of Civil Engineering and Management, 2004, 10(2), p. 131-141.

14. CEB Bulletin No 231. RC frames under earthquake loading. State of the art report. London: Thomas Teilford, 1996. 303 p.

15. ENV 1994-1-1: 2002E. Eurocode 4: Design of composite steel and concrete structures - Part1-1: General rules and rules for buildings. European Committee for Standardization, Brussels, Belgium, 2002. 180 p.

16. VROWENVELDER, A. C. W. M. Developments towards full probabilistic design codes. Structural Safety, 2002, 24(2-4), p. 417-432.

17. KUDZYS, Alg. Verification analysis of cast-in-situ reinforced concrete structures of framed multistorey buildings. Statyba (Civil Engineering), 1999, 5(3), p. 193-199 (in Lithuanian).

18. KUDZYS, A. Safety of power transmission line structures under wind and ice storms. Engineering Structures, 2006, 28(5), p. 682-689.

19. KLIUKAS, R.; KUDZYS, A. Probabilistic durability prediction of existing building elements. Journal of Civil Engineering and Management, 2004, 10(2), p. 107-112.

\section{APIE RAMSTYTINIŲ IR NERAMSTYTINIŲ STATIŠKAI NEIŠSPRENDŽIAMŲ KONSTRUKCIJŲ PROJEKTAVIMO YPATYBES}

A. Kudzys, R. Kliukas, A. Kudzys

Santrauka

Aptariama konstrukcinių ir technologinių ypatybių ịtaka statiškai neišsprendžiamų gelžbetoninių ir kompozitinių (plieninių-betoninių) konstrukcijų projektavimo metodologijai. Analizuojamos nuolatinès, kintamosios eksploatacinès, sniego ir vejjo apkrovos bei jų ekstremalios vertès. Du gamyklinių gelžbetoninių ir kompozitinių nekarpytujjų sijų bei rẻmsijų kaip ramstytinų ir neramstytinų elementų apkrovimo atvejai yra nagrinejjami atsižvelgiant i irąžu persiskirstymą jų ribiniame būvyje. Sijų ribiniam būviui patikrinti taikomi dalinių faktorių ir tikimybiniai metodai. Rekomenduojama sijų ilgalaikès išlikties tikimybę apskaičiuoti analitiniu transformuotų sąlyginių tikimybių metodu.

Reikšminiai žodžiai: nekarpytosios sijos, rèmsijos, ramstytinès konstrukcijos, poveikiai, dalinių faktorių metodas, tikimybinis patikimumas.

Algirdas KUDZYS. Dr Habil, Assoc Prof at the Dept of Building Structures of Architecture Faculty, Vilnius Gediminas Technical University, Saulètekio al. 11, LT-10223 Vilnius, Lithuania.

PhD (building structures, 1985), DEng (Japan, 1995), Dr Habil (2000). Research visit to Hokkaido University (Japan) 1990-92, Doctoral course research at Hakkaido University 1992-95. Author of two books, over 50 articles and 30 conference reports on load-carrying structures. Research interests: reinforced concrete, steel and masonry structures and their joints exposed to extreme gravity and lateral actions.

Romualdas KLIUKAS. Doctor, Assoc Prof, Dept of Strength of Materials, Vilnius Gediminas Technical University, Sauletekio al. 11, LT-10223 Vilnius, Lithuania.

$\mathrm{PhD}$ (building structures, 1989). Researcher at the Dept of Reinforced Concrete Structures of Vilnius Institute of Civil Engineering. Research visit to Buildings Scientific-Technical Research Centre (France) 1990-91. Author of over 40 articles. Research interests: durability and renovation of reinforced concrete structures, design features of hyperstatic and spun concrete structures.

Antanas KUDZYS. Dr Habil, Professor of the Institute of Architecture and Construction of Kaunas University of Technology, Tunelio g. 60, LT-44405 Kaunas, Lithuania.

Dr Habil (building structures, 1967). Author of 6 books, 5 textbooks for students, 4 dictionaries and over than 300 articles. Research interest: bearing capacity, safety and durability of structural members and their systems. 